International Journal of Scholarly Papers for Media and Communications

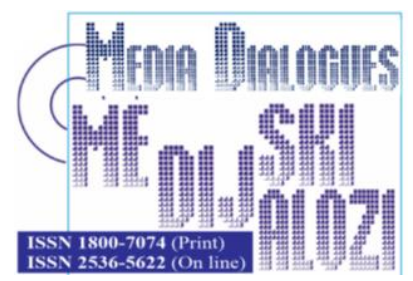

Janicic, R. (2020), „Arts and Media in Development of Destination Brand”, Media Dialogues / Medijski dijalozi, Vol. 13, No. 3, pp. 61-69.

\title{
Arts and Media in Development of Destination Brand
}

\author{
Professor RADMILA JANICIC, \\ University of Belgrade, Faculty of Organizational Sciences, \\ Belgrade, Serbia
}

\begin{tabular}{|c|c|}
\hline $\begin{array}{c}A R T I C L E \\
I N F O\end{array}$ & $\begin{array}{rll}\text { Received: December 12, } 2019 & / & \text { Revised from: January 11, } 2020 \\
\text { Accepted: February 10, } 2020 & / & \text { Available online: July 15, } 2020\end{array}$ \\
\hline DOI & $800-7074 / 13-3 / 6$ \\
\hline
\end{tabular}

\begin{abstract}
The paper presents theoretical and practical aspects of impact of arts on brand development of touristic destination on global market. The paper will analyze both theoretical and practical aspects of experience marketing of art's events on brand development of touristic destination. In empirical research the paper will present result about segmentation of target groups of tourists whose choose touristic destination on the base of cultural and art's events, as well as, their satisfaction with arts events, exhibitions, concerts, theatre's events, literature's event in the time when they were in chosen destination. Media which write about culture and art's events have impact on destination branding. Social media, by blog, vlog, post, have impact on development of destination brand.
\end{abstract}


KEY WORDS: Tourism, culture, arts, media communication, marketing strategies, communications.

\section{INTRODUCTION}

The subject of paper is theoretical and practical approach in development of destination brand by culture, art's and media. Experience marketing in tourism is new field of marketing research in academic institutions and scientific marketing associations. The goal of the paper is to develop touristic destination as brand, based on culture, arts and media. Specific goal of the paper is to enlighten strategies of experience marketing in destination branding, based on arts and media.

The paper gives overview of all experience marketing approach, experiental marketing tools, holistic marketing elements, internal marketing, integrated marketing, social responsible marketing and relationship marketing in tourism. Key hypothesis of the paper is that implementation of holistic marketing strategies in development of destination brand on global market place, based on culture and arts, is modern platform for development economy of one country. Good examples of implementation of culture and arts in development of brand destination on global market place is present in the paper. The paper present examples of exhibitons of Vincent van Gogh, Leonardo da Vinci as good implementation of marketing strategies in development of destination brand of the European cities.

\section{EXPERIENCE MARKETING, EXPERIANTAL TOOLS AND HOLISTIC MARKETING APPROACH IN DEVELOPMENT OF TOURISM, BASED ON ARTS}

Artistic projects have impact on development of tourism in one city. History facts prove that arts develop visits of tourists. Modern society needs cultural and arts content when they visit some city. (Janicic, 2018)

Holistic marketing approach has challenge in improving planning process of tourism. All parts of holistic marketing approaches are important, internal marketing, integrated marketing, relationship marketing and social responsible marketing. Internal marketing strategies improve touristic organizational structures and communications with team workers. Strategies of integrated marketing improve consistent of touristic services storytelling. Social responsible approach is base for every touristic services. Strategies of relationship marketing make platforms for clear and direct communications with target audiences of touristic services. In all these ways holistic marketing approach is base platform for realization of development of tourism (Kotler, 2017). 
Holistic marketing approach has integrated marketing communication with target audiences of touristic services, which present opportunities for research needs and wants of tourists. It is very important that integrated marketing communications have consistent storytelling with target audiences of touristic services (Pelsmacker, 2007).

Strategies of relationship marketing develop and improve communications between touristic institutions and their target groups. Social responsible approach gives platform for development of tourism, as well as, purpose and message to target groups. Strategies of relationship marketing have specific impact in leading of touristic development. They give opportunities of interactive communications with public, through traditional ways of communication and modern, social media. Two way communications give opportunities for listening of wants and needs of public, that shows ways for furture touristic development (Kotler, 2008).

The experiences are regarded as key concepts in marketing today, there are different views and interpretations about the content of terms. There are two connected concept of experience and experiential marketing. Based on the literature review the authors found that experience marketing is a strategic and a broader term than experiential marketing. Definition of experience marketing is that it is a strategic and holistic marketing of relevant and meaningful experiences, and experiential marketing as a tactical tool that helps to do marketing experientially. (Experience Marketing Association)

A consumers create meaning to all perceives. Experience represents a meaningful relationship between a person's perceptional activity and a life situation, and is of particular significance to the person. (Perttula 2007) When the customer experiences something to be important, this forms of life situations consisting of everything is in meaningful relationship (Leppiman, Same 2011). Experiences are formed out of these relationships and life situations. Fortezza and Pencarelli (2011) call it "packaging moments of life". 

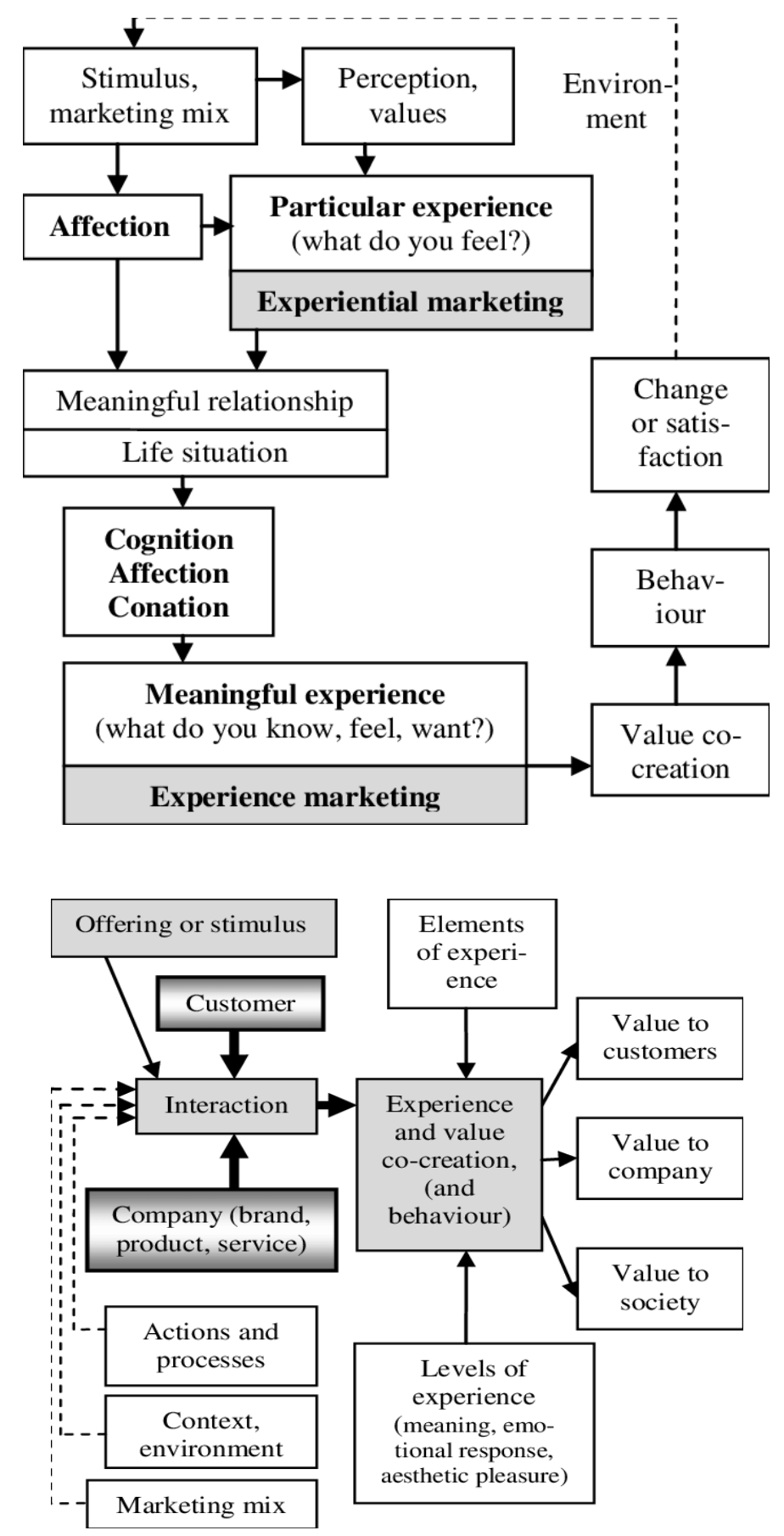

Figure 1. The difference between experience and experiential marketing Source: adaption of Leppiman, Same 2011. 
Experiential marketing is a marketing technique that creates experiences between brands and consumers. Experiential campaigns use an activation (for example product sampling, immersive experiences, stunts, events, etc.) to bring brands to life and interact directly with the target audience. (American Marketing Association)

\section{GOOD EXAMPLES OF IMPACT OF CULTURE AND ARTS ON DEVELOPMENT OF DESTINATION BRAND}

The good example of implementation of development of tourism, based on arts is world exhibition about work and life of Vincent van Gogh, named "Loving Vincent". Exhibition has shown in the European cities, London, Paris, Rome, Athens. Tourists come to visit exhibition and enjoy in cities. That artistic events improve tourism in cities where exhibition took place.

Tourists had opportunity to enjoy in touristic services in cities, as well as, to enjoy in exhibition. Visitors had opportunities to introduce work, life and thoughts of Vincent van Gogh. Specially touchable was room where he lived and work. The room was installed, just as real room, and visitors made pictures behind room. On down floor was multimedia story about Vincent's life and work. People could sit on the floor and look multimedia, animated movie. After projection, visitors could write comment in the yellow book in gallery, or online, on web site of exhibition, on Instagram, Facebook or Twitter pages. The comment was that visitors see beloved artist's work, but also introduced some biographical moments of his life. (Janicic, 2017)

The exhibition had attention of media, televisions, radio stations, as well as, social media. The exhibition bring artistic experience to visitors, who felt work and life of Vincent van Gogh. Touristic visits in the cities, that host exhibition, was doubled. It is prove that cultural and art's events impact on development of tourism on global market place.

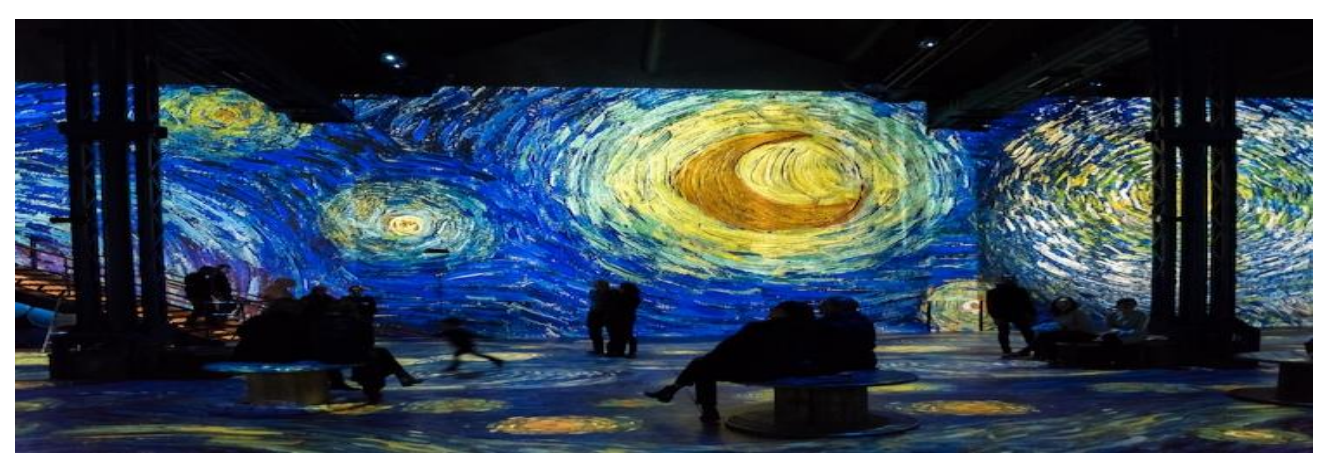




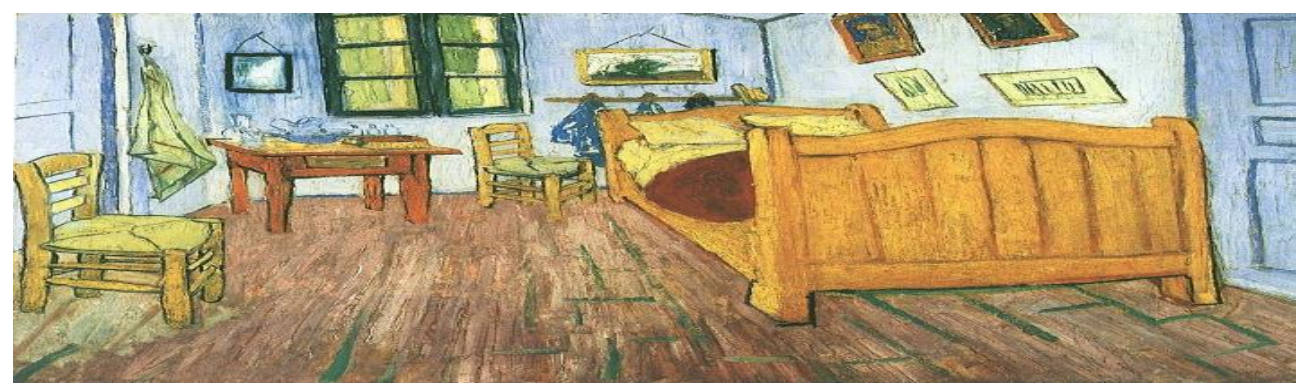

Figure 2. World's exhibition "Loving Vincent" (source: theguardian.com)

Good example of implementation of experience marketing of arts in development of tourism in European cities is exhibition "Leonardo da Vinci - 500 years of genius. The exhibition was present in London, Rome, Venice, Paris and Athens. In that time many tourists came to chosen city to enjoy in life of city and visit exhibition.

The exhibition gave whole view of Leonardo da Vinci work, life and thoughts. The first room presented Leonardo's machine works. Second room presented Leonardo's medical research of human body. Third room presented different views on Leonardo's favorite paintings "Mona Lisa". Families with children, young people, middle age people and retired people was visitors. They enjoyed in look on Leonardo's paintings. Special room presented Leonardo's painting "Secret dinner". In middle of exhibition was room where was presented multimedia artist's work, with his philosophical thoughts, such as "Nothing can be loved or hated unless it is first understood", "In time and with water, everything changes", "Water is the driving force in nature".

Comments on social media was that exhibition is brilliant as Leonardo da Vinci deserve. Specially young people was interested on his work, thoughts and life. Many young tourists come to London, Paris, Rome and Athens. Whole exhibition was sophisticate, and, also, strong experience, according to visitors comments, what inspired tourists around world to come and visit exhibition.

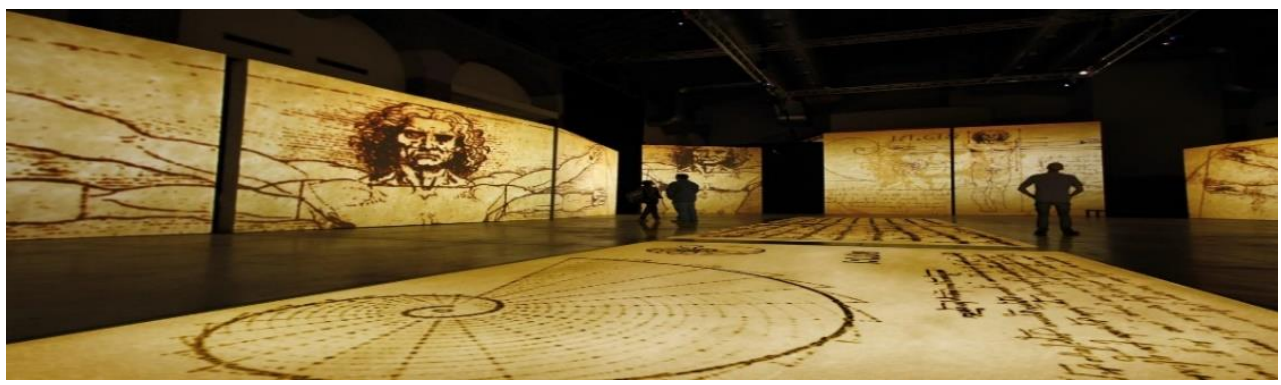




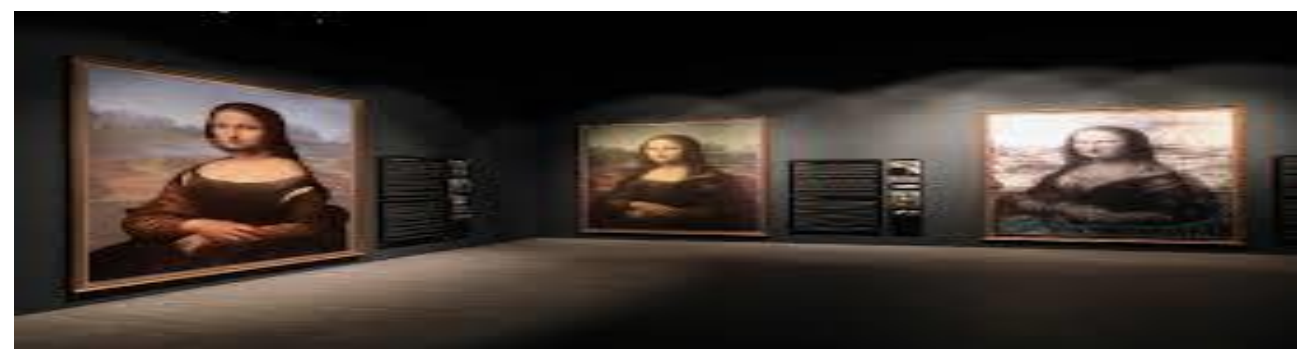

Figure 3. World exhibition "500 years of genius" (source: whyathens.com)

Author of this paper had opportunity to make focus group with touristic managers in touristic organization of Athens. Managers of this organization conclude that culture and arts have impact on development of tourism in Athens, especially tourists want to see Acropolis museum, National museum, Museum of Cycladic Arts, Modern Museum, as well as, Olympic stadion, National Greek Theatre. They emphasized that all aspects of holistic marketing approach is important, internal marketing, integrated marketing, relationship marketing, based on social responsible approach in development of tourism, based on culture and arts. Interesting is that they enlighten role of care about tourists, in the way that people, visitors feel that touristic institutions and organizations, hotels, hostels, restaurants, cafe bars, as well as, cultural and art's institutions care about them and their experience.

All these institutions touristic and artistic care about history, tradition, and in that way give brilliant experience to tourists. They emphasize that in implementation of marketing in development of tourism, based on arts and culture, it is important to be passionate about tourism, be kind in hospitality of tourists, respectful and sophisticate with tourists.

\section{MEDIA IN DEVELOPMENT OF DESTINATION BRAND}

Media contents about tourism, culture and art's events have impact on development of destination brand. Members of focus group, maagers of touristic destination, Athens, emphasized that it is imortant that offline and online media write in good way about society, people, hospitality, nature, culture, history, arts in Greece. Every year people come to Athens to visit historical places, to visit National Greek Theatre, as well as, galerries. Media in Greece enlighted mythology aspects of Greek history, arts and culture. People on social media share pictures of Athens and their experiences. Tourists write comments on social media, like Facebook, Twitter, expecially Instagram about their visit to Athens.

On the other side, managers of touristic organizations, emphasized that it is important to open Instagram profile of touristic organizations whose call tourists to 
send their pictures, as well as, managers call artists, photogrphers, painters to send their works, so all pages are focus on city of Athens. This city has slogan "Our Athens is your Athens!", as well as, "Live your myth!" All these content send message that Athens is historical, artistical city with kind people, with good hospitality.

\section{CONCLUSION}

Theoretical analysis, comparative analysis, examples from practice and focus group with managers in touristic organizations about implementation of culture and arts in development of tourism and destination brand, give conclusion that it is necessary to innovate marketing strategies in the field of tourism and branding od touristic destination. Touristic managers emphasize that in implementation of marketing in tourism, it is important to be passionate about hospitality, respectful and sophisticate and include culture and arts in development of touristic offers of one city. It is interesting that they enlighten role of care about tourists, in the way that tourists, visitors feel that touristic managers and art's institutions care about them and their experience. Media contents about tourism, culture and art's events have impact on development of destination brand. Social media gives opportunities to share experience about destination, to write comments and create groups to describe beloved destination brand. Media have role to improve destination as brand. It is known that tourists love cities, sich as, New York, London, Paris, Athens, Barcelona.

Specialized journals for tourism write about touristical important facts, but it is, also, important that daily newspaper write about ordinary touristic informations, cultural and art's events, about lifestyle of local people, tradition, music, history. It is very interesting that even movies impact on development of destination brand. Literature have impact on destination brand, by located storied on some city, describing flow of book in that city. Social media have the most important impact, because many vlogers have stories about experience in some city. They describe experiences, feeling, gastronomy, history, culture and arts of some city. Sinergia of all these elements impact on development of destination brand.

\section{LITERATURE}

Belch, G., Belch, M. (2012), Advertising and Promotion-An Integrated Marketing Communications Perspective, McGraw-Hill, New York.

Blakeman, R. (2006), Integrated Marketing Communication, McMillan, Toronto.

David, P. (2005), Integrated Marketing Communication. Toronto: Elsevier Inc.

Larry, P. (2008), Strategic Integrated Marketing Communication, Elsevier Inc., Toronto.

Janicic, R., Corovic, B. (2018), »Challenge of Holistic Marketing in Artistic Projects«, Marketing Magazine, Belgrade, Serbian Marketing Association (in Serbian). 
Kennet, C. (2008), Integrated Advertising, Promotion and Marketing Communication, Prentice Hall, New York..

Kostis Stankovic, M., Filipovic, V., Stavljanin, V. (2017), Marketing, Faculty of Organizational Sciences, Belgrade (in Serbian).

Kotler, Ph., Keller, L. (2008), Marketing management, $12^{\text {th }}$ Edition, Prentice Hall, New York.

Kotler, Ph., Keller, L. (2016), Marketing management, $15^{\text {th }}$ Edition, Prentice Hall, New York.

Pelsmacker, P., Geuens, M., Bergh, V. (2007), Marketing Communications, Prentice Hall, London.

Reid, N., King, W., DeLorme, E. (2008), „Top Level Agency Creatives Look at Advertising Creativity Then and Now", Journal of Advertising,.

Same, S., Larimo, J. (2012), „Experience and Experiental Marketing“, International conference on Business and Management, Vilnius. 